\title{
Determination of Brand Loyalty and Consumer Purchase Behaviour: A Study
}

\author{
Dr. Rambabu Lavuri ${ }^{1}$, Dr. D. Sreeramulu ${ }^{2}$ \\ Post Doctoral Fellow, Dept. of Business Management, Osmania University, Hyderabad, India. \\ Professsor, Dept. of Business Management, Osmania University, Hyderabad, India. \\ rambabu.lavuri@gmail.com; dsreeram25@rediffmail.com
}

\begin{abstract}
The current research paper investigated that to discover the effect of Barnd loyalty on Shoppers Purchase Decision with perceive to fmcg product and it altered into examined Barnd awareness, brand aptitude, attitude closer to Barnd loyalty, fulfillment with the guide of the brand, hazard avoidance to trade the items, Barnd trust with, Barnd image and their effect on customer decision. Wherein in the extent of check ended up restricted to hyderabad city. A shape survey changed into used to gauge the impact of Barnd loyalty and each age of the buyers focused in this examination view for to get the idea conduct of benefactor toward fmcg with product, with example length 784 respondents and tried through clear records, possibilities, anova, coreelation and a few relapse assessment through the utilization of spss 20.0 model. The final product of the take a gander at affirmed that Barnd loyalty essentially sway on the benefactor buy of clients and decided with media channels, validity of media ads, Barnd Awareness and Barnd loyalty factors altogether influence on shoppers decision. Barnd loyalty and purchaser buy thought having an incredible solid assocition between them. Brand Knowledge is one the components which effect on brand faithfulness. The shoppers having satisfacation towards purchasing decision by the Barnd loyalty.
\end{abstract}

Keywords: Brand faithfulness, Brand Awareness, Brand Loyalty, Brand Image, Barnd Trust, Consumer satisfaction.

\section{INTRODUCTION}

Shoppers purchase decision toward the Barnd loyalty refers the non-stop buy of the products or offerings from the identical agency in area of a opportunity services or products from a competitor. Shoppers purchase decision is the identification of a particular Brand inside the thoughts of the client and it has a significant effect on a Brand. the client belief does now not always have very much effect at the real overall performance of the product; while it is based totally at the modern-day-day recognition of Brand and product image with admire to the understanding of the customers. The customers belief is the method of influence of the Brand, statistics approximately the Brand which can result in transformation of Brand into Brand loyalty. The consumers decision inside the course of brand loyalty of the fmcg product is analyzed recognition, knowledge, Brand Awareness, chance aversion to trade the Brand, pleasure and Brand believe of the customers.

\section{LITERATURE REVIEW}

Ong Choon Hee., Woon Say Yen (2018) studied that Media advertising is one of the major tool which enhancing the consumers purchase decision and they conducted research at Malaysian meals and beverages industries context. The result shows that media like print, board costing and social media advertisements having greater influence or association on purchase behaviour of consumers, and last social media ads have strongest predictors of purchasing conduct of consumers. Tritama et al., (2016) evaluate the correlation between impact social media exposure and building the brand awareness of companies product, the final results show that the best advertising communication maintain companies revenues in effective manner, media is major tool to 
maintain new and existing customers by creating effective media exposure tools for the sale and create brand towards their product.

Ovidiu Ioan Moisescu (2009) examined the comparative behaviour between the brand recall and brand recognition in the case of durable and non durable items on urban Romanian consumers, and also reveal that their study explained that brand awareness is one of the dimensions of the brand equity and it is prerequisite of consumers buying selection. Brand awareness can also influence consumers' perceived threat evaluation and their self-assurance in the purchase choice, because of familiarity with the brand and its traits. They tries to expose the importance of unaided brand attention with regard to clients' shopping for decision and, aided Brand awareness when assessing the perceived risk associated with the purchase. Poranki and Kameswara (2015) take a look at that the client preference is widened with more brand Awareness a few of the purchasers and the impact on the patron pride will be measured greater appropriately. The consequences suggest that there is an impact of brand Awareness on patron pleasure with admire to product great, fee and size of the cigarettes and many others. To construct a strong Brand, brand recognition is necessary for such strength (Buil et al., 2013). Brand awareness differentiates the logo from competitors and results in brand preference (Valavi, 2014). Balaji (2011) noted that emblem focus influences the energy of brand relationships in the purchaser's mind. Aaker (1991) taken into consideration that brand recognition affords a client ok reason to don't forget the logo in his attention set. Brand awareness has been tested in customer' behaviour research (Hsu et al., 2011; Huang \& Cai, 2015; Bianchi \& Pike, 2010). Most fashions of patron' behaviour argued that awareness is a primary and vital step for deciding on the brand. Precisely, Brand focus considered a central detail of brand equity (Azad et al., 2013). Setyawan et al., (2015) indicates that best to variables like brand reputation, brand satisfaction, brand experience have massive effect to brand loyalty, they may be clients agree with in an employer and brand satisfaction. This studied that, an agency which produces an excessive involvement product has to conduct an effective advertising conversation with their costumer followed with a company have to boom their service so that purchasers will satisfy with their brand. Zhang, Yi. (2015) research have elaborated on the relationship between brand image and brand equity, followed by the concept, brand image has drawn huge attention from practitioners, as it is driving force of brand asset and brand performance and played an essential role in advertising activities to create awareness towards product and services. Kevin Lane Keller (2003) give an explanation for that In particular, in fairly competitive marketplaces, entrepreneurs frequently ought to link their brands to other entities. The study concludes that adopting broader, greater holistic perspectives that synthesize the multidimensional of brand expertise is important to improve branding principle and practice, both in trend and with brand leveraging particularly. And from Muhammad Ehsan Malik et al., (2013) the purpose of this endeavour is to become aware of the impact of brand awareness and brand loyalty on purchase purpose. The outcomes confirmed that brand awareness and brand loyalty have sturdy fantastic association with buy intention. Managers all over the global need to strive to sell the brand cognizance in conjunction with brand loyalty as both of them contribute closer to advantageous purchase intentions.

\section{OBJECTIVE ANd Hypothesis of THE STUdy}

The particular destinations of the examination are as per the following.

$\checkmark$ To observe the effect of media commuications on purchaser decision inside the direction of fmcg stock.

$\checkmark \quad$ To have a look at the credibility of media advertisements on Brand Knowledge towards fmcg Items.

$\checkmark \quad$ To evaluate the effectiveness of Brand Knowledge in terms of Building Brand Loyalty towards Consumer purchase decision.

$\checkmark \quad$ To find out the huge elements of Brand Layalty have an impact on shoppers satistisfcation.

To achieve the previously mentioned destinations, the accompanying speculation have been built up in the investigation.

American Research Journal of Business and Management

Page 2 
- $\quad \mathbf{H}_{\mathbf{0}}{ }^{1}$ : There is no massive impact of Brand Loyalty on socio-financial elements of Shoppers.

- $\quad \mathbf{H}_{\mathbf{0}}{ }^{2}$ : There is no enormous effect of Media commuications on shoppers decision closer to purchasing fmcg stocks.

- $\quad \mathbf{H}_{\mathbf{0}}{ }^{3}$ : There is no credibility of Media ads in terms of creating Brand Knowledge to shoppers towards Purchasing fmcg Items.

- $\quad \mathbf{H}_{\mathbf{0}}{ }^{4}$ : There is no impact of Brand Knowlege on the shoopers brand loyalty towards purchasing products.

- $\mathbf{H}_{\mathbf{0}}{ }^{5}$ : There may be no effect of Brand Loyalty factors on shoppers purchase decision towards fmcg products.

\section{Materials ANd Methods}

The research method is a strategy of investigation, in the present study used these ways to prove the association of respected variables like Socio economic fcators of the shoppers, Brand Loyalty, Brand knowledge, Brand Awareness, Brand trust, Brand Image, Influence media and Media credibility on the Purchase decision of shoopers/clints. The current research paper adopts an analytical research layout hasbeen used. It is based on Determination of Brand layalty and Purchase decision. The smaple Data collected from the two states of india, those are Telangna (Secunderabad, Hyderabda and warangal) and Andhra pradesh (Vijayawada and Amaravathi) as a Sampling Area.

Sources of Records: the study is worried in the path of Brand loyalty and purchaser belief with respective fmcg merchandise. The records gathered from primary resources and secondary resources, number one deliver of information is amassed from the respondents via mounting questionnaire and direct interviews with respect fmcg shoppers. Secondary information is collected from various journals, periodicals including magazines, business newspapers, and from problems related books and web sites. In the present study, an extensive use of both Primary data and secondary data has been used. Primary data were collected from respondents from two states with respected fove cities, those are Secunderabad, Hyderabda, Warangal, Vijayawada and Amaravathi. The respondents who give information's regarding their Understandings, experiences, satisfaction, problems facing and satisfcation towards Brand Loyalty.

Sample Design: Convenience sampling technique has been used to target the respondents, Sample size was 784 respondents from Sampling area. This research was based mainly on primary data and the instrument for collecting the data were questionnaire and facts has been gathered the usage of the starcture questionnaire via survey technique and personal interview with personnel. The questionnaire consisted of open and close ended questions, Likert five point scale was used for measuring the opinions of respondents. Each question measured different perceptions regarding the variables of Brand Loyalty. The respondents were asked to rate their responses towards four dimensions and respected items on a 5-point scale ranging from Strongly Disagree (1), Disagree (2), Neutral (3), Agree (4), and Strongly Agree (5). The data were examined using the Statistical Equipment like frequency, mean, anovas, Correlation and a couple of regression the use of SPSS 20.0.

\section{CONSEQUENCES AND Discusions}

To test the reliability of the facts, cronbach's alpha check is performed.

Table1. Scale Construction

\begin{tabular}{|l|c|c|}
\hline \multicolumn{1}{|c|}{ Questionnaire } & Items & Alpha \\
\hline Media Communications & 5 Items & 0.761 \\
\hline Media credibilities & 4 Items & 0.773 \\
\hline Brand Awareness & 3 Items & 0.801 \\
\hline
\end{tabular}

American Research Journal of Business and Management 
Determination of Brand Loyalty and Consumer Purchase Behaviour: A Study

\begin{tabular}{|l|l|c|}
\hline Brand Knowledge & 3 Items & 0.795 \\
\hline Brand Loyalty & 3 Items & 0.811 \\
\hline Brand Trust & 3 Items & 0.799 \\
\hline Brand Image & 3 Items & 0.788 \\
\hline Customer Satisfacation & 3 Items & 0.769 \\
\hline
\end{tabular}

From the above disk results shown that the authentication of validity and reliability of present studies paper. Main variables are Media Communications, Media credibilities, Brand Awareness, Brand Knowledge, Brand Loyalty, Brand Trust, Brand Image and Customer Satisfacation. Alpha values were calculated one after the other for each the variables to test for the reliability and validity of the destiny take a look at. The Cronbach's alpha values for Media Communications, Media credibilities, Brand Awareness, Brand Knowledge, Brand Loyalty, Brand Trust, Brand Image and Customer Satisfacation are observed to be 0.761, 0.773, 0.801, 0.795,0.811, $0.799,0.788$ and 0.769 .

(a) Demographic Variables Details of the Respondents: the frequency distribution of demographic variables is supplied within the following desk.

Table2. Demographic details of the respondents

\begin{tabular}{|c|c|c|c|}
\hline & Classification & No of Responses & Percentage \\
\hline \multirow{5}{*}{ Age } & $20-25$ & 174 & 22.2 \\
\hline & $26-30$ & 219 & 27.9 \\
\hline & 31-35 & 214 & 27.3 \\
\hline & $36-40$ & 132 & 16.8 \\
\hline & 41 and above & 45 & 5.7 \\
\hline \multirow{2}{*}{ Gender } & Male & 554 & 70.7 \\
\hline & Female & 230 & 29.3 \\
\hline \multirow{4}{*}{ Education } & Below degree & 172 & 22.0 \\
\hline & Degree & 220 & 28.1 \\
\hline & $\mathrm{PG}$ & 258 & 32.9 \\
\hline & Above PG & 134 & 17.1 \\
\hline \multirow{5}{*}{ Occupation } & Govt Employee & 240 & 30.6 \\
\hline & Private Employee & 281 & 35.8 \\
\hline & Business & 93 & 11.9 \\
\hline & Home Maker & 82 & 10.5 \\
\hline & Student & 88 & 11.2 \\
\hline \multirow{5}{*}{$\begin{array}{l}\text { Monthly income } \\
\text { (in rupees) }\end{array}$} & Below 20,000 & 81 & 10.3 \\
\hline & $20,001-30,000$ & 117 & 14.9 \\
\hline & $30.001-40,000$ & 303 & 38.6 \\
\hline & $40,001-50,000$ & 193 & 24.6 \\
\hline & 50,001 and above & 90 & 11.5 \\
\hline Total & & $n=784$ & $100 \%$ \\
\hline
\end{tabular}

- Age in years: With regard to the age distribution of the respondents, it changed into determined that majority of them belonged to the age institution of 26-30years $27.9 \%$, those belonging 31-35 years of the 


\section{Determination of Brand Loyalty and Consumer Purchase Behaviour: A Study}

age accounted for $27.3 \%$, while the ones inside the age group of $20-25$ years accounted for $22.2 \%$, 36-40 years accounted for $16.8 \%$, and 41 and above years accounted for $6.5 .7 \%$ of the full respondents.

- Gender: A near examine the desk reveals that the male respondents accounted for a higher percent $70.7 \%$, when examine woman respondents $29.3 \%$.

- Education: With respect to the educational repute, $32.9 \%$ of the respondents had cozy submit PG, $28.1 \%$ of the respondents had been graduation, and $22 \%$ of them were Below Degree and $17.1 \%$ of them had been above PG.

- Occupation: As it is able to be seen from above desk, the profession of the respondents inside the case of $35.8 \%$ of the respondents from private worker; even as 30.6\% reported from Govt Employee, $11.9 \%$ from Business, $11.2 \%$ from at ease the Students and $10.5 \%$ of respondents from Home Maker.

- Income in rupees: As it is able to be seen from table 3, the profits of the respondents inside the case of $38.6 \%$ of the respondents ranged from Rs.30,001-40,000; at the same time as $24.6 \%$ mentioned to have a monthto-month income Rs. $40.001-50,000 ; 14.9 \%$ of the respondents suggested month-to-month earnings $20,001-30,000 ; 11.5 \%$ of respondents earning 50,001 and above, $10.3 \%$ of the respondents stated monthly income below 20,000 .

(b) Results of ANOVAs: In connection with the above, the analysis further proceds to find out the most impotnt factors which have been taken into account by the repsondents sample decision towards brand loyalty. In this regard, The Analysis of varience (ANOVAs) test is used to find out the mean difference between the selected samples by using F-distribution value.

- $\quad \mathbf{H}_{\mathbf{0}}{ }^{1}$ : There is no massive impact of Brand Loyalty on socio-financial elements of Shoppers.

Table3. ANOVA

\begin{tabular}{|c|l|c|c|c|c|c|}
\hline \multicolumn{2}{|c|}{} & Sum of Squares & $\mathrm{df}$ & Mean Square & $\mathrm{F}$ & Sig. \\
\hline \multirow{4}{*}{ Age in years } & Between Groups & 224.560 & 8 & 28.070 & 25.575 & .000 \\
\cline { 2 - 7 } & Within Groups & 850.622 & 775 & 1.098 & & \\
\cline { 2 - 7 } & Total & 1075.182 & 783 & & & \\
\hline \multirow{4}{*}{$\begin{array}{c}\text { Education } \\
\text { Gender }\end{array}$} & Between Groups & 27.005 & 8 & 3.376 & 19.304 & .000 \\
\cline { 2 - 7 } & Within Groups & 135.520 & 775 & .175 & & \\
\cline { 2 - 7 } & Total & 162.526 & 783 & & & \\
\hline & Between Groups & 102.392 & 8 & 12.799 & 10.141 & .000 \\
\cline { 2 - 7 } & Within Groups & 978.174 & 775 & 1.262 & & \\
\cline { 2 - 7 } & Total & 1080.566 & 783 & & & \\
\hline \multirow{3}{*}{$\begin{array}{c}\text { Income in } \\
\text { rupees }\end{array}$} & Between Groups & 46.092 & 8 & 5.762 & 3.418 & .001 \\
\cline { 2 - 7 } & Within Groups & 1306.192 & 775 & 1.685 & & \\
\cline { 2 - 7 } & Total & 1352.284 & 783 & & & \\
\cline { 2 - 7 } & Between Groups & 115.790 & 8 & 14.474 & 12.939 & .000 \\
\cline { 2 - 7 } & Within Groups & 866.939 & 775 & 1.119 & & \\
\hline
\end{tabular}

The table-3 shows the results of ANOVAs, Brand loyalty impact on socio-financial elements of Shoppers like age, gender, schooling, profession, earnings in rupees and their $\mathrm{f}$ values discovered to be statistically significant, which means there by using there's good sized effect of Brand loyalty on socio-financial elements of Shoppers, followed with values of Age: $f(8,775)=25.575, p<0.05$, Gender $f(8,775)=19.304, p<.05$, Education: $f(8,775)$ 
Determination of Brand Loyalty and Consumer Purchase Behaviour: A Study

$=10.141, \mathrm{p}<.05$; Occupation: $\mathrm{f}(8,775)=3.418, \mathrm{p}<.05$, Income in rupees: $\mathrm{f} f(8,775)=12.939, \mathrm{p}<.05$. Finally, it reveals that there is massive influence of brand loayalty on the socio-financial elements of Shoppers.

- $\quad \mathbf{H}_{\mathbf{o}}{ }^{2}$ : There is no enormous effect of Media commuications on shoppers decision closer to purchasing fmcg stocks.

Table4. ANOVA

\begin{tabular}{|c|c|c|c|c|c|c|}
\hline & & Sum of Squares & $\mathrm{df}$ & Mean Square & $\mathrm{F}$ & Sig. \\
\hline \multirow{3}{*}{$\mathrm{TV}$} & Between Groups & 251.791 & 10 & 25.179 & 44.139 & .000 \\
\hline & Within Groups & 440.962 & 773 & .570 & & \\
\hline & Total & 692.754 & 783 & & & \\
\hline \multirow{3}{*}{ Radio } & Between Groups & 94.373 & 10 & 9.437 & 10.768 & .000 \\
\hline & Within Groups & 677.483 & 773 & .876 & & \\
\hline & Total & 771.856 & 783 & & & \\
\hline \multirow{3}{*}{$\begin{array}{l}\text { Newspaper \& } \\
\text { Magazine }\end{array}$} & Between Groups & 45.231 & 10 & 4.523 & 9.020 & .000 \\
\hline & Within Groups & 387.615 & 773 & .501 & & \\
\hline & Total & 432.846 & 783 & & & \\
\hline \multirow{3}{*}{ Outdoor } & Between Groups & 139.030 & 10 & 13.903 & 23.215 & .000 \\
\hline & Within Groups & 462.929 & 773 & .599 & & \\
\hline & Total & 601.959 & 783 & & & \\
\hline \multirow{3}{*}{ Internet } & Between Groups & 39.019 & 10 & 3.902 & 4.546 & .000 \\
\hline & Within Groups & 663.419 & 773 & .858 & & \\
\hline & Total & 702.438 & 783 & & & \\
\hline
\end{tabular}

It is evident that from the above desk, media communications like TV, radio, newspaper \& magazine, outside and net and their $\mathrm{f}$ values found to be statistically significant, which means there by statistically significant effect of media communications on shoppers decision towards purchsing the items, followed with values of television: $\mathrm{f}(10,773)=44.139, \mathrm{p}<.05$, radio: $\mathrm{f}(10,773)=10.768, \mathrm{p}<.05$, newspaper \& magazine: $\mathrm{f}(10,773)=$ 9.020, $\mathrm{p}<.05$; Outdoor: $\mathrm{f}(10,773)=23.215, \mathrm{p}<.05$, internet: $\mathrm{f}(10,773)=4.546, \mathrm{p}<.05$. So, Media Communication had significant effect on shoopers purchasing decision.

- $\quad \mathbf{H}_{\mathbf{o}}{ }^{3}$ : There is no credibility of Media ads in terms of creating Brand Knowledge to shoppers towards Purchasing fmcg Items.

Table5. ANOVA

\begin{tabular}{|l|l|c|c|c|c|c|}
\hline \multicolumn{2}{|c|}{} & Sum of Squares & Df & Mean Square & F & Sig. \\
\hline \multirow{4}{*}{ Diff. Media ads } & Between Groups & 68.166 & 10 & 6.817 & 6.159 & .000 \\
\cline { 2 - 7 } & Within Groups & 855.547 & 773 & 1.107 & & \\
\cline { 2 - 7 } & Total & 923.713 & 783 & & & \\
\hline \multirow{2}{*}{$\begin{array}{l}\text { Media ads } \\
\text { appeals }\end{array}$} & Between Groups & 132.775 & 10 & 13.277 & 14.095 & .000 \\
\cline { 2 - 7 } & Within Groups & 728.163 & 773 & .942 & & \\
\cline { 2 - 7 } $\begin{array}{l}\text { Diff. media } \\
\text { vehicles }\end{array}$ & Total & 860.938 & 783 & & & \\
\hline & Between Groups & 150.832 & 10 & 15.083 & 23.878 & .000 \\
\cline { 2 - 7 } & Within Groups & 488.279 & 773 & .632 & & \\
\hline
\end{tabular}

American Research Journal of Business and Management

Page 6 
Determination of Brand Loyalty and Consumer Purchase Behaviour: A Study

\begin{tabular}{|l|l|c|c|c|c|c|}
\hline \multirow{2}{*}{$\begin{array}{l}\text { Celebrity } \\
\text { endorsement in } \\
\text { media ads }\end{array}$} & Between Groups & 86.167 & 10 & 8.617 & 7.370 & .000 \\
\cline { 2 - 7 } & Within Groups & 903.751 & 773 & 1.169 & & \\
\cline { 2 - 7 } & Total & 989.918 & 783 & & & \\
\hline
\end{tabular}

it is evident that from the above disk, credibility of media classified ads like diff. Media commercials, media commercials appeals, diff. Media vehicles and celebrity endorsement in media commercials and their $\mathrm{f}$ values discovered to be statistically significnat towards creating better brand knowledge toshoopers, that means there by using there is credibility of media ads on shoppers for build brnad knowledge, followed with values of diff. Media ads: $\mathrm{f}(10,783)=6.159, \mathrm{p}<.05$, media ads appeals: $\mathrm{f}(10,783)=14.095, \mathrm{p}<.05$, diff. Media cars: $\mathrm{f}(10,783)=$ $23.878, \mathrm{p}<.05$; Celebrity endorsement in media ads: $\mathrm{f}(10,783)=7.370, \mathrm{p}<.05$. Since, all significance values are smaller than p-value, so media credibility having positive influence on shoopers to build brnd knowledge.

- $\mathbf{H}_{\mathbf{0}}{ }^{4}$ : There is no impact of Brand Knowlege on the shoopers brand loyalty towards purchasing products.

Table6. ANOVA

\begin{tabular}{|l|l|c|c|c|c|c|}
\hline \multicolumn{2}{|c|}{} & Sum of Squares & Df & Mean Square & F & Sig. \\
\hline \multirow{3}{*}{$\begin{array}{l}\text { Brand } \\
\text { Awareness }\end{array}$} & Between Groups & 82.169 & 10 & 8.217 & 5.998 & .000 \\
\cline { 2 - 7 } & Within Groups & 1058.942 & 773 & 1.370 & & \\
\cline { 2 - 7 } Brand Trust & Total & 1141.111 & 783 & & & \\
\hline \multirow{4}{*}{ Brand Image } & Between Groups & 85.353 & 10 & 8.535 & 12.936 & .000 \\
\cline { 2 - 7 } & Within Groups & 510.030 & 773 & .660 & & \\
\cline { 2 - 7 } & Total & 595.383 & 783 & & & \\
\hline & Between Groups & 20.864 & 10 & 2.086 & 2.890 & .001 \\
\cline { 2 - 7 } & Within Groups & 558.136 & 773 & .722 & & \\
\cline { 2 - 7 } & Total & 579.000 & 783 & & & \\
\hline
\end{tabular}

The above table- 6 reveal that, thers is any significant impact of brand knowlege elements to build soppers brand loayalty for purchasing selected productss, followed by the brand knowledge elements like Brand Awareness, Brand Trust and Brand Image and their $\mathrm{f}$ values discovered to be statistically significant, that means there is significant impact of Brand Knowledge to creat and build brand loyalty of shoppers for purchasing. Followed with values of Brand Awareness: $\mathrm{f}(10,773)=5.998, \mathrm{p}<.05$, Brand Trust: $\mathrm{f}(10,773)=12.936, \mathrm{p}<.05$, Brand Image: $f(10,773)=2.890, p<.05$. Hence, all variables significance values are smaller than $p$-value, it indicates there is stronge impact of brand knowledge to build brand loaylty in shoppers mind.

- $\quad \mathbf{H}_{\mathbf{0}}{ }^{5}$ : There may be no effect of Brand Loyalty factors on shoppers purchase decision towards fmcg products.

Table7. ANOVA

\begin{tabular}{|c|l|c|c|c|c|c|}
\hline \multicolumn{2}{|c|}{} & Sum of Squares & $\mathrm{df}$ & Mean Square & $\mathrm{F}$ & Sig. \\
\hline \multirow{3}{*}{$\begin{array}{c}\text { Brand } \\
\text { Awareness }\end{array}$} & Between Groups & 407.433 & 10 & 40.743 & 41.909 & .000 \\
\cline { 2 - 7 } & Within Groups & 751.504 & 773 & .972 & & \\
\cline { 2 - 7 } & Total & 1158.938 & 783 & & & \\
\hline \multirow{3}{*}{$\begin{array}{c}\text { Brand } \\
\text { Knowledge }\end{array}$} & Between Groups & 113.977 & 10 & 11.398 & 11.874 & .000 \\
\cline { 2 - 7 } & Within Groups & 742.002 & 773 & .960 & & \\
\cline { 2 - 7 } & Total & 855.980 & 783 & & & \\
\hline
\end{tabular}

American Research Journal of Business and Management

Page 7 
Determination of Brand Loyalty and Consumer Purchase Behaviour: A Study

\begin{tabular}{|c|c|c|c|c|c|c|}
\hline \multirow{3}{*}{$\begin{array}{l}\text { Mindset toward } \\
\text { Brand Loyalty }\end{array}$} & Between Groups & 246.265 & 10 & 24.626 & 22.703 & .000 \\
\hline & Within Groups & 838.489 & 773 & 1.085 & & \\
\hline & Total & 1084.754 & 783 & & & \\
\hline \multirow{3}{*}{ Brand Image } & Between Groups & 104.689 & 10 & 10.469 & 16.665 & .000 \\
\hline & Within Groups & 485.591 & 773 & .628 & & \\
\hline & Total & 590.281 & 783 & & & \\
\hline \multirow{3}{*}{ Brand Trust } & Between Groups & 53.714 & 10 & 5.371 & 8.760 & .000 \\
\hline & Within Groups & 473.995 & 773 & .613 & & \\
\hline & Total & 527.709 & 783 & & & \\
\hline \multirow{3}{*}{$\begin{array}{c}\text { Customer } \\
\text { Satisfaction }\end{array}$} & Between Groups & 199.255 & 10 & 19.926 & 36.375 & .000 \\
\hline & Within Groups & 423.438 & 773 & .548 & & \\
\hline & Total & 622.694 & 783 & & & \\
\hline
\end{tabular}

From the table-7, resutls reveal that Brand loyalty elements like Brand Awareness, Brand Knowledge, mindset toward Brand loyalty, Customer satisfcation by the brand, Brand trust and brand image and their $\mathrm{f}$ values discovered to be statistically significant, that means there with the aid of there may be large impact of Brand layolty factors, observed with values of Brand Awareness: $f(10,773)=41.909$, $p<.05$; Brand Knowledge: $\mathrm{f}(10,773)=11.874, \mathrm{p}<.05$; mindset toward Brand loyalty: $\mathrm{f}(10,773)=22.703, \mathrm{p}<.05$; Customer satisfcation by the brand: $f(10,773)=36.375, p<.05$; Brand trust: $f(10,773)=8.760, p<.05$; Brand image: $f(10,773)=16.665$, $\mathrm{p}<.05$ and their significance values are smaller than $\mathrm{p}$-value. so there is a significant imapct of brnad loyalty on shooper purchasing decisions.

(c) Results of Pearson Correlation: In order to understand the Degree of associaiton between the two sets of variables, which are considered in the current study. The numerical values of Pearson correlation reflect the degree of association between selected Brand loyalty variables and consumer purchase behaviour in the current study.

Correlation between selected variables and purchase notion towards FMCG

Table8. Correlation

\begin{tabular}{|l|l|c|}
\hline S.No & Variables & Correlation $(r)$ \\
\hline 1 & Media Communnication & $.575^{*}$ \\
\hline 2 & Brand Trust & $.683^{*}$ \\
\hline 3 & Brand Image & $.630^{* *}$ \\
\hline 4 & Brand Awareness & $.759^{* *}$ \\
\hline 5 & Brand knowledge & $.763^{* *}$ \\
\hline 6 & Brand Loyalty & $.797^{* *}$ \\
\hline 7 & Customer Satisfcation & $.621^{*}$ \\
\hline
\end{tabular}

**. Correlation is significant at the 0.01 level.

*. Correlation is significant at the 0.05 level.

From the above disk, the correlation results show that there is a strong correlation between Brand Devotion and consumer purchase notion with $r=0.797$ at the $5 \%$ significance level. Followed by Brand knowledge and Brand Awareness having same with 0.763 and 0.759 at the $5 \%$ significance level with positive correlation with 
consumer purchase notion. Variable like Media Vehicles $(r=0.575)$ and Brand Trust $(r=0.683)$ having a positive correlation with consumer purchase at $1 \%$ significance level.

(d) Results of Multiple Regression: Multiple regression is a statistical method that uses several explanatory variables to predict the outcome of a reaction variable. it's far used to explain the relationship among one continuous based variable and or greater impartial variables.

- $\quad \mathbf{H}_{\mathbf{0}}{ }^{1}$ : There is no massive impact of Brand Loyalty on socio-financial elements of Shoppers.

Table9. Model Summary

\begin{tabular}{|c|c|c|c|c|c|c|}
\hline Model & $\mathrm{R}$ & R Square & Adjusted R Square & Std. Error of the Estimate & $\mathrm{F}$ & Sig. \\
\hline 1 & $.346^{\mathrm{a}}$ & .519 & .114 & .51752 & 23.074 & $.000 \mathrm{~b}$ \\
\hline
\end{tabular}

a. Dependent Variable: Brand Devotion

b. Predictors: (Constant), income in rupees, gender, Occupation, age in years, education

$\mathrm{R}^{2}$ price is found to be 0.519 , meaning there by that $51.9 \%$ of the version in established variable is defined through predictors. Since the $\mathrm{f}$ fee is discovered to be large, the null hypothesis is rejected and opportunity speculation well-known, meaning there by way of that there's a giant difference within the variation resulting from predictors.

Table10. Coefficients of variables

\begin{tabular}{|c|c|c|c|c|c|c|}
\hline & \multirow{2}{*}{ Model } & \multicolumn{2}{|c|}{ Un standardized Coefficients } & \multirow{2}{*}{\begin{tabular}{|c|} 
Standardized Coefficients \\
Beta \\
\end{tabular}} & \multirow{2}{*}{$\mathrm{t}$} & \multirow{2}{*}{ Sig. } \\
\hline & & $\mathrm{B}$ & Std. Error & & & \\
\hline \multirow{6}{*}{1} & (Constant) & 4.000 & .115 & & 34.928 & .000 \\
\hline & Age In Years & -.152 & .017 & -.325 & -9.003 & .003 \\
\hline & Gender & .112 & .042 & .177 & -5.013 & .001 \\
\hline & Education & .143 & .020 & .089 & 2.148 & .000 \\
\hline & Occupation & .145 & .015 & .109 & -3.069 & .002 \\
\hline & Income in Rupees & .174 & .020 & .147 & -3.716 & .000 \\
\hline
\end{tabular}

From the above desk, it's far evident that income in rupees (0.174) is emerged as the maximum critical demo graphical variables that's considerably effect with the aid of Brand Devotion, and its significantly specific from 0 due to the fact its $\mathrm{p}$-value is less than 0.000 , which is smaller than 0.05 . Observed through the Occupation (.145), schooling (.143) having high impact through the Brand Devotion and gender is drastically unique from 0 due to the fact its $p$-value is 0.001 , And additionally consequences proven that there may be a low/ negative impact of Brand Devotion on demo graphical variables i.e. age (-.152), however is appreciably extraordinary, due to the fact its p-value (0.03) is much less than 0.05 .

- $\mathbf{H}_{\mathbf{o}}{ }^{2}$ : There is no enormous effect of Media commuications on shoppers decision closer to purchasing fmcg stocks.

Table11. Model Summary

\begin{tabular}{|c|c|c|c|c|c|c|}
\hline Model & $\mathrm{R}$ & R Square & Adjusted R Square & Std. Error of the Estimate & $\mathrm{F}$ & Sig. \\
\hline 1 & $.290^{\mathrm{a}}$ & .484 & .079 & .36659 & 15.588 & $.000^{\mathrm{b}}$ \\
\hline
\end{tabular}

a. Dependent Variable: Consumer Perception

b. Predictors: (Constant), TV, Radio, Newspaper \& Magazine, Outdoor and Internet. 
Determination of Brand Loyalty and Consumer Purchase Behaviour: A Study

R2 fee is determined to be zero.484, which means there by way of that $48.4 \%$ of the version in established variable is defined with the aid of predictors. Since the F-value (15.588) is discovered to be massive, the null hypothesis is rejected and opportunity speculation familiar, that means there through that there is a giant difference in the version caused by predictors.

Table12. Coefficients of variables

\begin{tabular}{|c|c|c|c|c|c|c|}
\hline \multirow{2}{*}{\multicolumn{2}{|c|}{ Model }} & \multicolumn{2}{|c|}{ Un standardized Coefficients } & \multirow{3}{*}{$\begin{array}{c}\text { Standardized Coefficients } \\
\text { Beta } \\
\end{array}$} & \multirow{3}{*}{$\begin{array}{c}\mathrm{t} \\
2.369 \\
\end{array}$} & \multirow{3}{*}{$\begin{array}{l}\text { Sig. } \\
.000 \\
\end{array}$} \\
\hline & & \multirow{2}{*}{$\begin{array}{c}\mathrm{B} \\
3.437 \\
\end{array}$} & \multirow{2}{*}{$\begin{array}{c}\text { Std. Error } \\
.081\end{array}$} & & & \\
\hline \multirow{6}{*}{1} & (Constant) & & & & & \\
\hline & $\mathrm{TV}$ & .118 & .012 & .023 & .630 & .000 \\
\hline & Radio & .034 & .030 & .041 & 1.128 & .260 \\
\hline & Newspaper \& Magazine & .042 & .014 & .126 & -2.993 & .003 \\
\hline & Outdoor & .011 & .010 & .039 & 1.086 & .008 \\
\hline & Internet & .115 & .014 & .328 & 8.146 & .000 \\
\hline
\end{tabular}

From the above desk, it's far glaring that TV (0.118) is emerged as the maximum vital media channel that is substantially impact on client notion with respect to fmcg merchandise, and its substantially distinctive from 0 because its p-value is much less than 0.000 , that is smaller than 0.05 . Observed with the aid of the internet (.115), newspaper \& Magazine (.042) having excessive impact on client notion and those are substantially one of a kind from 0 because its p-values are less than 0.05 , whereas radio is not statistically widespread because its $\mathrm{p}$ - value $(0.34)$ is greater than 0.05 .

- $\mathbf{H}_{\mathbf{0}}{ }^{3}$ : There is no credibility of Media ads in terms of creating Brand Knowledge to shoppers towards Purchasing fmcg Items

Table13. Model Summary

\begin{tabular}{|c|c|c|c|c|c|c|}
\hline Model & $\mathrm{R}$ & R Square & Adjusted R Square & Std. Error of the Estimate & F & Sig. \\
\hline 1 & $.436^{\mathrm{a}}$ & .390 & .185 & 1.10441 & 39.975 & $.000^{\mathrm{b}}$ \\
\hline
\end{tabular}

a. Dependent Variable: Consumer Perception

b. Predictors: (Constant), Diff. Media ads, Media ads appeals, Diff. media vehicles , Celebrity endorsement.

$\mathrm{R} 2$ cost is determined to be 0.390 , which means there by that $39.0 \%$ of the variation in structured variable is defined through predictors. Since the F-value (39.975) is discovered to be giant, the null speculation is rejected and opportunity speculation common, that means there via that there's a huge distinction in the version due to predictors.

Table14. Coefficients of variables

\begin{tabular}{|c|c|c|c|c|c|c|}
\hline & \multirow{2}{*}{ Model } & \multicolumn{2}{|c|}{ Un standardized Coefficients } & \multirow{2}{*}{\begin{tabular}{|c|} 
Standardized Coefficients \\
Beta \\
\end{tabular}} & \multirow{2}{*}{$\mathrm{T}$} & \multirow{2}{*}{ Sig. } \\
\hline & & $\mathrm{B}$ & Std. Error & & & \\
\hline \multirow{5}{*}{1} & (Constant) & 1.995 & .244 & & 8.164 & .000 \\
\hline & Diff. Media ads & .134 & .036 & .129 & 3.723 & .000 \\
\hline & Media ads appeals & -.076 & .090 & -.029 & -.848 & .007 \\
\hline & Diff. media vehicles & .080 & .042 & .075 & 1.895 & .008 \\
\hline & Celebrity endorsement & .425 & .032 & .457 & 13.473 & .000 \\
\hline
\end{tabular}




\section{Determination of Brand Loyalty and Consumer Purchase Behaviour: A Study}

From the above desk, it's miles glaring that movie star endorsement $(0.425)$ is emerged as the maximum credibility in media commercials which is significantly effected on client notion, and its notably one of a kind from 0 due to the fact its p-value is much less than 0.000 , which is smaller than 0.05 . Accompanied through the diff. Media commercials (.134), diff. Media vehicles (.080) having high credibility in media advertisements and impact on purchaser perception and these are drastically different from 0 because its p-values are much less than zero.05.

- $\mathbf{H}_{\mathbf{0}}{ }^{4}$ : There is no impact of Brand Knowlege on the shoopers brand loyalty towards purchasing products.

Table15. Model Summary

\begin{tabular}{|c|c|c|c|c|c|c|}
\hline Model & R & R Square & Adjusted R Square & Std. Error of the Estimate & F & Sig. \\
\hline 1 & $.463^{\mathrm{a}}$ & .214 & .204 & .24078 & 20.996 & $.000^{\mathrm{b}}$ \\
\hline
\end{tabular}

a. Dependent Variable: Brand Devotion

b. Predictors: (Constant), Brand Awareness, Brand Trust, Brand Image.

$\mathrm{R} 2$ cost is determined to be 0.214 , which means there by that $21.4 \%$ of the variation in structured variable is defined through predictors. Since the F-value (20.996) is discovered to be giant, the null speculation is rejected and opportunity speculation common, that means there via that there's a huge distinction in the version due to predictors.

Table16. Coefficients of variables

\begin{tabular}{|c|l|c|c|c|c|c|}
\hline \multirow{2}{*}{ Model } & \multicolumn{2}{|c|}{ Un standardized Coefficients } & Standardized Coefficients & \multirow{2}{*}{ T } & \multirow{2}{*}{ Sig. } \\
\cline { 3 - 7 } & B & Std. Error & Beta & & \\
\hline \multirow{3}{*}{1} & 3.189 & .195 & & 16.311 & .000 \\
\cline { 2 - 7 } & (Constant) & .167 & .036 & .113 & 1.882 & .001 \\
\cline { 2 - 7 } & Brand Awareness & .178 & .023 & .201 & 3.337 & .001 \\
\cline { 2 - 7 } & Brand Trust & .159 & .024 & .398 & 6.721 & .000 \\
\hline
\end{tabular}

From the above disk, it's far evident that Brand Awareness (0.167) is emerged because the maximum impact Brand Awareness issue on client perception and its considerably one of a kind from 0 because its p-cost is less than 0.000, that's smaller than 0.05. Followed with the aid of the Brand Trust (.178), Brand Image (.159) are having high effect on Barnd Devotion in the direction of consumer purchase notion towards fmcg stock, and these are drastically one-of-a-kind from 0 due to the fact its $p$-values are less than 0.05 .

- $\quad \mathbf{H}_{\mathbf{0}}{ }^{5}$ : There may be no effect of Brand Loyalty factors on shoppers purchase decision towards fmcg products.

Table17. Model Summary

\begin{tabular}{|c|c|c|c|c|c|c|}
\hline Model & R & R Square & Adjusted R Square & Std. Error of the Estimate & F & Sig. \\
\hline 1 & $.328^{\mathrm{a}}$ & .618 & .102 & .32015 & 20.521 & $.000^{\mathrm{b}}$ \\
\hline
\end{tabular}

a. Dependent Variable: Consumer Perception

b. Predictors: (Constant), Emblem Awareness, Emblem Knowledge, Attitude towards emblem Loyalty, Satisfaction by the Emblem, Risk Aversion to Change the Products, Emblem Trust, Emblem Image.

$\mathrm{R} 2$ value is found to be 0.618 , that means there by using that $61.8 \%$ of the variation in based variable is defined via predictors. For the reason that $\mathrm{f}$ value (20.521) is discovered to be sizable, the null hypothesis is rejected 
and alternative hypothesis usual, which means there by that there is a considerable distinction in the variant because of predictors.

Table18. Coefficients of variables

\begin{tabular}{|c|c|c|c|c|c|c|}
\hline & \multirow[t]{2}{*}{ Model } & \multicolumn{2}{|c|}{$\begin{array}{l}\text { Un standardized } \\
\text { Coefficients }\end{array}$} & \multirow{2}{*}{$\begin{array}{c}\begin{array}{c}\text { Standardized } \\
\text { Coefficients }\end{array} \\
\text { Beta } \\
\end{array}$} & \multirow[t]{2}{*}{$\mathrm{t}$} & \multirow[t]{2}{*}{ Sig. } \\
\hline & & $\mathrm{B}$ & Std. Error & & & \\
\hline \multirow{8}{*}{1} & (Constant) & 3.946 & .097 & & 40.609 & .000 \\
\hline & Emblem Awareness & .145 & .014 & .358 & -10.136 & .000 \\
\hline & Emblem Knowledge & .100 & .036 & .096 & -2.778 & .006 \\
\hline & Attitude towards Brand Emblem & -.071 & .017 & -.172 & 4.234 & .000 \\
\hline & Satisfaction by the Emblem & .120 & .013 & .330 & -9.521 & .000 \\
\hline & Risk Aversion to Change the Products & .021 & .017 & .012 & .064 & .009 \\
\hline & Emblem Trust & .154 & .026 & .073 & -2.053 & .000 \\
\hline & Emblem Image & .135 & .012 & .083 & -1.999 & .006 \\
\hline
\end{tabular}

From the above table, it's far evident that Emblem Trust (0.154) is emerged because the maximum impact Emblem loyalty issue on client perception and its considerably one of a kind from 0 because its p-cost is less than 0.000, that's smaller than 0.05. Followed with the aid of the Emblem Awareness (.145), Emblem Image (.135), Satisfaction by the Emblem (.120), emblem information(.100) are having high effect on customer belief in the direction of fmcg products, and these are drastically one-of-a-kind from 0 due to the fact its p-values are less than 0.05 .

\section{ConCLUSIONS}

Brand loyalty and purchaser decision can be evolved via giving greater pride to customers. Patron decision constantly enhance through the offering exceptional brand cost of the fmcg products. The existing research paper explored on effect brand loyalty/ faithfulness on purchaser decision and it changed into analyzed socioeconomic factors of clients, particular media channels which is probably encouraged more to consumers within the direction of fmcg products observed with credibility of media classified ads and brand loyalty elements like brand attention, brand know-how, mind-set toward brand loyalty, satisfaction through the brand, chance aversion to exchange the products, brand trust, brand image. It's miles positioned that from the ANOVA and more than one regression evaluation brand loyalty factors, media channels, credibility of media advertisements having incredible effect on purchaser belief in the path of fmcg products. Media channels and media classified ads are the stimulation s elements to beautify brand price, records and recognition and brand image in clients thoughts with recognize of the fmcg products. The high-quality brand loyalty is constantly giving consumer pride, and it is the essential aspect for developing fantastic feeling on consumer belief even as shopping fmcg products. The results of Correlation reveal that there is a robust linear Relatoinship between brand Loyalty and consumer purchase notion, followed by brand knowledge and brand Awareness having positive correlation at the 5\% significance level and Variable like Media Vehicles and brand Trust having a positive correlation with consumer purchase at $1 \%$ significance level.

\section{MANAGERIAL IMPLICATIONS}

The significant ramifications of the ebb and flow inquire about is that organization the board ought to enhance factors like to improve the apparent nature of items, brand association, brand mindfulness, brand Knowledge, brand image, brand trust by the assistance of the best media vehicle with incredible plugs advertisements for building client enchant towards their item portions. And furthermore its improves connections between 
organizations items and total faithfulness to image by the client amuse. The executives can invigorate purchasers to expound upon their seal decision by animating the inspiration and the limit of the buyers to assess their brand decision by the select seal. At last, clear and justifiable data ought to be given about the brand. The executives ought to likewise be worried about obvious brand unwaveringness which is additionally founded on duty and keep away from any of the elements that may make the buyer's loss of steadfastness brand.

\section{Limitations AND DiRECTION FOR FUTURE STUDY}

- Then have a look at might be finished to recognize the effect of brand loyalty on patronizing decision in the direction of fmcg products.

- The pattern decided on might not constitute the whole population. For this reason, the hassle of generalization can be there.

- In view that few classes in fmcg merchandise take into consideration, customer decision in the whole fmcg zone can not be measured and it is chance for further research as is a lot of other products from different segments which can be considered for the future study

- The studies can be made further exhaustive by including Rural and different socio - economic sections of the population.

- There is a chance of doing further research on the bases of consumers psychological factors like and motivation, learning, personality, perception, and attitude external forcesfactors like reference groups, culture, Family and social class.

\section{REFERENCES}

1. Aaker, D. A. (1991). Managing brand equity: The free press.

2. Anton A Setyawan, Kussudiyarsana, Imronudin. (2015). Brand Trust and Brand Loyalty, an Empirical Study in Indonesia Consumers. British Journal of Marketing Studies. Vol.4, No.3, pp.37-47.

3. Bagus Tritama., Hansel \& Tarigan., Riswan. (2016). The Effect of Social Media to the Brand Awareness of A Product of A Company. CommIT (Communication and Information Technology) Journal, vol. 10, no. 1, pp. 9-14, (10. 9. 10.21512/commit.v10i1.1667).

4. Balaji, M. (2011). Building strong service brands: the hierarchical relationship between brand equity dimensions. The IUP Journal of Brand Management, 8 (3), 7-24.

5. Bianchi, C., \& Pike, S. D. (2010). An application of the CBBE model to assess brand loyalty for a long haul travel destination. In (September) Global Marketing Conference, 9-12.

6. Buil, I., de Chernatony, L., \& Martínez, E. (2013). Examining the role of advertising and sales promotions in brand equity creation. Journal of Business Research, 66 (1), 115-122.

7. Dr. Muhammad Ehsan Malik., Muhammad Mudasar Ghafoor., Hafiz Kashif Iqbal., Usman Riaz., Noor ul Hassan., Muhammad Mustafa \& Saleh Shahbaz.(2013). Importance of Brand Awareness and Brand Loyalty in assessing Purchase Intentions of Consumer. International Journal of Business and Social Science Vol. 4 No. 5; May 2013.

8. Hsu, C. H., Oh, H., \& Assaf, A. G. (2011). A customer-based brand equity model for upscale hotels. Journal of Travel Research, 51 (1), 81-93.

9. Huang, Z. J., \& Cai, L. A. (2015). Modeling consumer-based brand equity for multinational hotel brandsWhen hosts become guests. Tourism Management, 46, 431-443. 
10. Jang hyeon Nam ., Yuksel Ekinci Georgina Whyatt. (2011). Brand equity, brand loyalty and consumer satisfaction. Annals of Tourism Research,Volume 38, Issue 3, Pages 1009-1030.

11. Kevin Lane Keller.(2003). Brand Synthesis: The Multidimensionality of Brand Knowledge, Journal of Consumer Research, Volume 29, Issue 4, March 2003, Pages 595 600,https://doi.org/10.1086/346254

12. Ong Choon Hee., Woon Say Yen. (2018). The Influence of Advertising Media towards Consumer Purchasing Behaviour in the Food and Beverage Industry in Malaysia. International Journal of Human Resource Studies, ISSN 2162-3058, 2018, Vol. 8, No. 2.

13. Ovidiu Ioan Moisescu.(2009). The Importance of Brand Awareness in Consumer's Buying Decision and Perceived Risk Assessment. Management \& Marketing, 7(1):103-110.

14. Poranki. Kameswara. (2015). The Impact of Brand Awareness on Customer Satisfaction: A Case Study of Godfrey Phillips India Limited, India. Research Journal of Social Science \& Management (RJSSM). 5. 38-44.

15. Valavi, P. (2014). Factors influencing mobile services adoption: a brand- equity perspective. International Journal of Research in Social Sciences, 4 (3), 1-18.

16. Zhang, Yi. (2015). The Impact of Brand Image on Consumer Behaviour: A Literature Review. Open Journal of Business and Management. 03. 58-62. 10.4236/ojbm.2015.31006.

Citation: Dr. Rambabu Lavuri, Dr. D. Sreeramulu. "Determination of Brand Loyalty and Consumer Purchase Behaviour: A Study". American Research Journal of Business and Management. 2019; 5(1): 1-14.

Copyright (c) 2019 Dr. Rambabu Lavuri, Dr. D. Sreeramulu. This is an open access article distributed under the Creative Commons Attribution License, which permits unrestricted use, distribution, and reproduction in any medium, provided the original work is properly cited. 